\title{
Probiotic effect on reserve mobilization in late stage pregnancy in goats
}

\author{
A. El Bachir Bouchicha, N. Mimoune ${ }^{*}$ S. Djouadi, A. Kalem, R. Kaidi and \\ D. Khelef
}

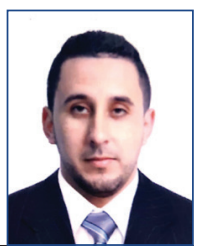

\begin{abstract}
This study was carried out to evaluate a probiotic effect on the mobilisation of body reserves in goats towards the end of gestation by measuring ketone body production in blood and calculating the body condition score (BCS). Ketone body production was monitored by measuring the betahydroxybutyrate BHB levels in the blood using a portable kit (PRECISION XTRA
\end{abstract}

Blood ketone test). The results revealed that the use of the probiotic SYMBIOVEBA ${ }^{\circledR}$ (association of Saccharomyces cervicae and Lactobacillus) did not decrease the formation of blood BHB in goats, and therefore did not decrease mobilization of the body reserves of goats in late pregnancy.

Key words: $B C S$; Betahydroxybutiric acid; goats; peripartum; probiotic; reserve mobilization

\section{Introduction}

Food deficiency towards the end of gestation can cause a nutritional imbalance, which can have a negative impact on health and compromise gestation (El-Deeb and El-Bahr, 2017). The measurement of ketone bodies, mainly betahydroxybutyrate (BHB), allows for monitoring the animal's energy balance (Sadjadian et al., 2012; Folnožić et al.,

2015; Vince et al., 2017; Aladrović et al., 2018; Szenci et al., 2018; Folnožić et al., 2019; Đuričić et al., 2020). However, there are currently few standards in effect for the use of this biochemical marker in goats. Threshold values used to prevent metabolic disorders are often extrapolated from values for dairy cows or ewes (Đuričić et al., 2011; Doré et al., 2013).

Ahmed El Bachir BOUCHICHA, Laboratory of Biotechnologies related to animal reproduction (LBRA), Institute of Veterinary Sciences, Saad Dahleb University, Blida, Algeria, Institute of Sciences and Technology, Tissemsilt University, Algeria; Nora MIMOUNE*, (Corresponding author, e-mail: nora. mimoune@gmail.com), Laboratory of Biotechnologies related to animal reproduction (LBRA), Institute of Veterinary Sciences, Saad Dahleb University, Blida, Algeria, National High School of Veterinary Medicine, Animal Health and Productions Laboratory. El-Alia, Algiers, Algeria; Sohaib DJOUADI, Faculty of Nature \& Life Sciences, Farm Animal Reproduction Laboratory, University of Tiaret, Algeria; Ammar KALEM, Laboratory of Biotechnologies related to animal reproduction (LBRA), Institute of Veterinary Sciences, Saad Dahleb University, Blida, Algeria; Rachid KAIDI, Laboratory of Biotechnologies related to animal reproduction (LBRA), Institute of Veterinary Sciences, Saad Dahleb University, Blida, Algeria; Djamel KHELEF, National High School of Veterinary Medicine, Animal Health and Productions Laboratory. ElAlia, Algiers, Algeria 
The antibiotics previously widely used as additives in livestock feed have since been banned from use. Indeed, their consumption exposes the animal and the consumer to antibiotic resistance from certain pathogens (Cvetnić et al., 2016; Saidi et al., 2021). In this context, probiotics, as more natural additives, present an interesting alternative (Haimoud-Lekhal et al., 1999).

Probiotics are living microorganisms that can have beneficial effects by improving the intestinal flora (Fuller, 1989). It has been shown that the provision of probiotics (yeasts or bacteria) improves the digestibility of nutrients, and optimizes ruminal fermentation, which leads to high growth performances of animals (Cole et al., 2008). Therefore, the aim of this study was to evaluate the effect of a commercial probiotic $\left(\mathrm{SYMBIOVEBA}^{\circledR}\right)$ administered to goats on the mobilization of body reserves, by measuring the formation of ketone bodies, mainly $\mathrm{BHB}$, and calculating the body condition score.

\section{Material and methods}

\section{Study area}

The study was carried out in the region of Bouaarfa, Blida, in northern Algeria, in the Blidean Atlas Mountains.

\section{Animals}

In this study, 91 local goats belonging to the Arbya population were divided into two groups: the first was given a probiotic at the rate of $10 \mathrm{~mL} /$ goat/ month (the experimental group), and the second was the control group, without the administration of the probiotic. The dose of the probiotic was diluted in 10 $\mathrm{mL}$ water, and administered using a measuring device.

\section{Food management}

Goat feed was exclusively at pasture, except during harsh winter periods (rain or snow), with the ad libitum distribution of fodder (alfalfa hay), and the mandatory addition of $400 \mathrm{~g}$ concentrate per goat per day.

Flushing was applied four weeks before control to prepare females for service, with an average supplemental distribution of $400 \mathrm{~g}$ concentrate per goat per day for fat goats, and $500 \mathrm{~g}$ concentrate for lean goats. On the other hand, females were prepared for kidding and the lactation by steaming during the last two months of gestation ( $4^{\text {th }}$ and $5^{\text {th }}$ month), supplemented with $400 \mathrm{~g}$ concentrate per goat per day, and the experimental group also received $10 \mathrm{~mL}$ probiotic per goat per month (SYMBIOVEBA ${ }^{\circledR}$, MarcoPolo Environmental-group, Italy). Goats received two meals, distributed at 7 a.m. and 5 p.m.

\section{Reproduction management}

The protocol followed the synchronization method established by Cognie (1988) that is based on blocking the cycle in the luteal phase by progestogens. Fluorogestone acetate (FGA) was incorporated into vaginal sponges at a rate of $20 \mathrm{mg}$ per sponge. It stimulates the luteal phase and ensures blockage of follicular growth. Intramuscular injection of 400 IU Pregnant Mare Serum Gonadotropin (PMSG) after 9 days of sponge placement then stimulates follicular growth and maturation. The sponges were removed on the $11^{\text {th }}$ day.

Goats were presented for mating on the $13^{\text {th }}$ day after the start of treatment, and remained for 2 days. When the females returned to heat after few weeks, they were presented again for the males.

\section{Blood ketone measurement}

Blood ketone levels were evaluated using a portable PRECISION XTRA BLOOD KETON TEST device (Abbott). The measurement of BHB rates showed a high correlation $(\mathrm{r}=0.95)$ with standard 
laboratory analyses of goats reported by Doré et al. (2013).

BHB measurement began 6 weeks before the expected delivery date, then every 15 days (4 measurements at $-6,-4,-2$ weeks and on the day of parturition). Blood samples were taken and BHB measurements were performed on site at the farm, in the early morning (6 a.m.).

\section{Body condition scoring}

The estimation of the body condition score (BSC) on a scale of 6 grades (0 to $5)$ with an accuracy of 0.25 points as proposed by Santucci and Maestrini (1985) and validated by Hervieu et al. (1991). Lumbar palpation combined with a sternal palpation was performed at three time periods: at the time of mating, 2 months before kidding, and at the time of parturition.

\section{Statistical study}

Statistical analysis was performed using IBM SPSS (version 20.2013) and included descriptive analysis and comparison with the ANOVA test. The significance level was set at 5\%.

\section{Results and discussion \\ Effect of probiotic on BHB levels towards the end of gestation}

The BHB blood concentrations changed throughout the experiment period (the final six weeks before parturition) (Table 1), for the control group (without probiotic) and the experimental group (with probiotic).

The results shows that the first group had similar levels of $\mathrm{BHB}$ compared to the control group at 6 weeks before parturition $(0.28 \mathrm{mmol} / \mathrm{L}$ and 0.30 $\mathrm{mmol} / \mathrm{L}, \quad$ respectively, $\quad P=0.13)$. This

Table 1. Evolution of blood BHB (mmol/L) in both groups during the period of six weeks before parturition

\begin{tabular}{|c|c|c|c|c|}
\hline $\begin{array}{c}\text { Prepartum } \\
\text { weeks }\end{array}$ & Group 1 $(\boldsymbol{n}=\mathbf{4 5})$ & Group 2 $(\boldsymbol{n}=\mathbf{4 6})$ & MSE & $P$ \\
\hline-6 & 0.28 & 0.30 & 0.07 & 0.13 \\
\hline-4 & 0.32 & 0.35 & 0.10 & 0.20 \\
\hline-2 & 0.37 & 0.42 & 0.13 & 0.10 \\
\hline 0 & 0.47 & 0.51 & 0.18 & 0.23 \\
\hline
\end{tabular}

MSE: Mean Standard Error

Table 2. Effect of probiotic on BCS between breeding and parturition

\begin{tabular}{|c|c|c|c|c|c|}
\hline \multirow{2}{*}{ BCS at } & Zone & Group 1 (n=45) & Group 2 (n=46) & MSE & $P$ \\
\hline \multirow{2}{*}{ Breeding } & Sternal & 2.81 & 2.98 & 0.05 & 0.08 \\
& Lumbar & 2.27 & 2.46 & 0.05 & 0.08 \\
\hline \multirow{2}{*}{$\begin{array}{c}\text { months before } \\
\text { parturition }\end{array}$} & Sternal & 2.77 & 2.90 & 0.07 & 0.36 \\
\hline \multirow{2}{*}{ Parturition } & Sumbar & 2.19 & 2.32 & 0.06 & 0.38 \\
\hline & Lumbar & 2.18 & 2.25 & 0.07 & 0.67 \\
\hline
\end{tabular}


similarity was further observed during the last month of gestation with the three measurements, which revealed a non-significant difference $(P=0.20$ and $P=0.10$, respectively at -4 and -2 weeks before parturition, $P=0.23$ at the time of parturition).

\section{Probiotic effect on BCS}

The assessment of the body condition score is a simple feeding management tool, that makes it possible to adjust rations at key periods (Domecq et al., 1997). The evolution of BCS during the gestation period in this experiment is presented in Table 2.

The BCS scores obtained show that the probiotic had no effect on the deposition of fat in the sternal and lumbar regions, and that there was no difference at the end of gestation between the two groups. During the final third of gestation and after probiotic supplementation, there was a decrease in BCS in both groups, and the averages recorded at the time of parturition for the group 1 (sternal $\mathrm{BCS}=2.18$ and lumbar $\mathrm{BCS}=1.49$ ) and the control group (sternal $B C S=2.25$ and lumbar $B C S=1.61$ ) revealed no significant difference $(P=0.67$ for the sternal BCS and $P=0.41$ for the lumbar BCS). In dairy cows, Temim et al. (2009) mentioned that Saccharomyces cerevisiae supplementation only slightly modified prepartum BCS, with a non-significant difference of $11 \%$ on average compared to control cows $(P=0.32)$ and similar to that recorded between the start of supplementation (last two weeks of gestation) and parturition was revealed.

\section{Conclusion}

This study on the probiotic effect (Saccharomyces cervicae and Lactobacillus) on the mobilization of body reserves in the local Arbya goat at the end of gestation, carried out in extensive breeding in a mountainous area, revealed that this probiotic has no effect on reducing the accumulation of $\mathrm{BHB}$ in the blood at the end of gestation in local goats. Accordingly, the use of this product does not reduce the risk of mobilization of body reserves in either the sternal or lumbar regions. Further large investigations to confirm the data are required in the future.

\section{Acknowledgments}

The authors are grateful to the staff of the Atlas Cap Association for the assistance provided in carrying out this work.

\section{References}

1. ALADROVIĆ, J., M. PAVKOVIC, B. BEER-LJUBIC, L. VRANKOVIC AND Z. STOJEVIC (2018): Metabolic profile in Holstein dairy cow herd. Vet. stn. 49, 9-18. (In Croatian).

2. COGNIE, Y. (1988): Nouvelles méthodes utilisées pour améliorer les performances de reproduction chez les brebis. INRA Prod. Anim. 2, 83-92.

3. COLE, N. A. and R. W. TODD (2008): Opportunities to enhance per-formance and efficiency through nutrient synchrony in concentrate-fed ruminants. J. Anim. Sci. 86, 318-333.

4. CVETNIĆ, I., M. BENIĆ, B. HABRUN, G. KOMPES, M. STEPANIĆ and M. SAMARDŽIJA (2016): Outbreak and Elimination of Cow Mastitis on a Small Dairy Farm - a Case Report. Vet. stn. 47, 387394. (In Croatian).

5. DOMECQ, J. J., A. L. SKIDMORE, J. W. LLOYD and J. B. KANEENE (1997): Relationship between body condition scores and conception at first artificial insemination in a large dairy herd of high yielding Holstein cows. J. Dairy Sci. 80, 113-120.

6. DORÉ, V., J. DUBUC, A. M. BÉLANGER and S. BUCZINSKI (2014): Evaluation of the accuracy of an electronic on-farm test to quantify blood béathydroxybutyrate concentration in dairy goats. Dairy Sci. 96, 4505-4507.

7. ĐURIČIĆ, D., T. DOBRANIĆ, J. GRIZELJ, D. GRAČNER, I. HARAPIN, D. STANIN, I. FOLNOŽIĆ, I. GETZ, D. CVITKOVIĆ and M.SAMARDŽIJA(2011): Concentrations of Total Proteins and Albumins, and AST, AP, CK and GGT Activities in the Blood Serum Boer and Saanen Goats During Puerperium. Reprod. Dom. Anim. 46, 674-677.

8. ĐURIČIĆ, D., B. BEER LJUBIĆ, S. VINCE, R. TURK, H. VALPOTIĆ, I. ŽURA ŽAJA, N. MAĆEŠIĆ, M. BENIĆ, I. GETZ and M. SAMARDŽIJA (2020): Effects of dietary clinoptilolite supplementation on $\beta$-hydroxybutirate serum level and milk fat to protein ratio during early lactation in Holstein-Friesian cows. Micropor. Mesopor. Mat 292, 109766, 4. 
9. EL-DEEB, M. W. and S. M. EL-BAHR (2017): Biomarkers of ketosis in dairy cows at postparturient period: acute phase proteins and pro-inflammatory cytokines. Vet. arhiv 87, 431-440.

10. FOLNOŽIĆ, I., R. TURK, D. ĐURIČIĆ, S. VINCE, J. PLEADIN, Z. FLEGAR-MEŠTRIĆ, H. VALPOTIĆ, T. DOBRANIĆ, D. GRAČNER and M. SAMARDŽIJA (2015): Influence of Body Condition on Serum Metabolic Indicators of Lipid Mobilization and Oxidative Stress in Dairy Cows During the Transition Period. Reprod. Domest. Anim. 50, 910-917.

11. FOLNOŽIĆ, I., M. SAMARDŽIJA, D. ĐURIČIĆ, S. VINCE, S. PERKOV, S. JELUŠIĆ, H. VALPOTIĆ, B. BEER LJUBIĆ, M. LOJKIĆ, D. GRAČNER, I. ŽURA ŽAJA, N. MAĆEŠIĆ, J. GRIZELJ, T. DOBRANIĆ, G. REDŽEPI, Z. ŠOSTAR, R. TURK (2019): Effects of in-feed clinoptilolite treatment on serum metabolic and antioxidative biomarkers and acute phase response in dairy cows during pregnancy and early lactation. Res. Vet. Sci. 127, 57-64.

12. FULLER, R. (1989): Probiotics in man and animals. J. Appl. Microbiol. 66, 365-378.

13. SADJADIAN, R., H. A. SEIFI, M. MOHRI, A. A NASERIAN and N. FARZANEH (2012): Variations of energy biochemical metabolites in periparturient dairy Saanen goats. Comp. Clin. Pathol. 22, 449-456.

14. SAIDI, R., Z. CANTEKIN, N. MIMOUNE, Y. ERGUN, H. SOLMAZ, D. KHELEF and R. KAIDI (2021): Investigation of the presence of slime production, VanA gene and antiseptic resistance genes in Staphylococci isolated from bovine mastitis in Algeria. Vet. stn. 52, 57-63.

15. SZENCI, O., Z. SZELÉNYI, L. LÉNÁRT, D. BUJÁK, L. KOVÁCS, L. F. KÉZÉR, B. HAN and A. HORVÁTH (2018): Importance of monitoring the peripartal period to increase reproductive performance in dairy cattle. Vet. stn. 49, 297-307.

16. TEMIM, S., A. BOUDJENAH, B. DJELLOUT, S. BOUZERD, M.E.ATIF,F.HAFSI,F.GHOZLANEand H. AIN BAZIZ (2009): Effet de la complémentation alimentaire en levure Saccharomyces cerevisiae sur les performances zootechniques et les paramètres sanguins de la vache laitière en peripartum. Livest. Res. Rural. Dev. 21, 187.

17. VINCE, S., D. ĐURIČIĆ, H. VALPOTIĆ, D. GRAČNER, I. FOLNOŽIĆ, B. ŠPOLJARIĆ, P. SOBIECH and M. SAMARDŽIJA (2017): Risk factors and prevalence of subclinical ketosis in dairy cows in Croatia. Vet. arhiv 87, 13-24.

\section{Probiotički učinak na mobilizaciju tjelesnih rezervi u kasnoj gravidnosti koza}

Ahmed El Bachir BOUCHICHA, Laboratory of Biotechnologies related to animal reproduction (LBRA), Institute of Veterinary Sciences, Saad Dahleb University, Blida, Algeria, Institute of Sciences and Technology, Tissemsilt University, Algeria; Nora MIMOUNE, Laboratory of Biotechnologies related to animal reproduction (LBRA), Institute of Veterinary Sciences, Saad Dahleb University, Blida, Algeria, National High School of Veterinary Medicine, Animal Health and Productions Laboratory. El-Alia, Algiers, Algeria; Sohaib DJOUADI, Faculty of Nature \& Life Sciences, Farm Animal Reproduction Laboratory, University of Tiaret, Algeria; Rachid KAIDI, Laboratory of Biotechnologies related to animal reproduction (LBRA), Institute of Veterinary Sciences, Saad Dahleb University, Blida, Algeria; Djamel KHELEF, National High School of Veterinary Medicine, Animal Health and Productions Laboratory. El-Alia, Algiers, Algeria

Ova je studija provedena da bi se procijenio probiotički učinak na mobilizaciju tjelesnih rezervi koza na kraju njihove gravidnosti, uzimajući u obzir proizvodnju ketonskih tijela u krvi i ocjenu tjelesne kondicije (BCS). Proizvodnja ketonskih tijela praćena je mjerenjem razina betahidroksibutirata (BHB) $\mathrm{u}$ krvi uporabom prijenosnog kompleta (PRECISION XTRA test za ketone $\mathrm{u}$ krvi).
Dobiveni rezultati pokazali su da uporaba probiotika SYMBIOVEBA $^{\circledR} \quad$ (kombinacija Saccharomyces cervicae i lactobacillus) nije smanjila formiranje BHB-a u krvi koza te time nije smanjila mobilizaciju njihovih tjelesnih rezervi u kasnoj gravidnosti.

Ključne riječi: $B C S, \beta$-hidroksibutirična kiselina, koze, peripartum, probiotik, mobilizacija rezervi 